\title{
Correction to: An approach to achieve overall farm feed efficiency in pig production: environmental evaluation through individual life cycle assessment
}

Tara Soleimani $^{1,1} \cdot$ Helene Gilbert $^{1}$

Published online: 19 May 2021

(c) The Author(s) 2021

Correction to: The international journal of life cycle assessment https://doi.org/10.1007/s11367-020-01860-3

The original version of this article unfortunately contained a mistake. The presentations of Fig. 4 was incorrect. The corrected figure is given.

The original article can be found online at https://doi.org/10.1007/ s11367-020-01860-3.

Tara Soleimani

tara.soleimani@inrae.fr

1 GenPhySE, Université de Toulouse, INRAE, F-31326,

Castanet-Tolosan, Toulouse, France 
Fig. 4 Impacts visual comparison

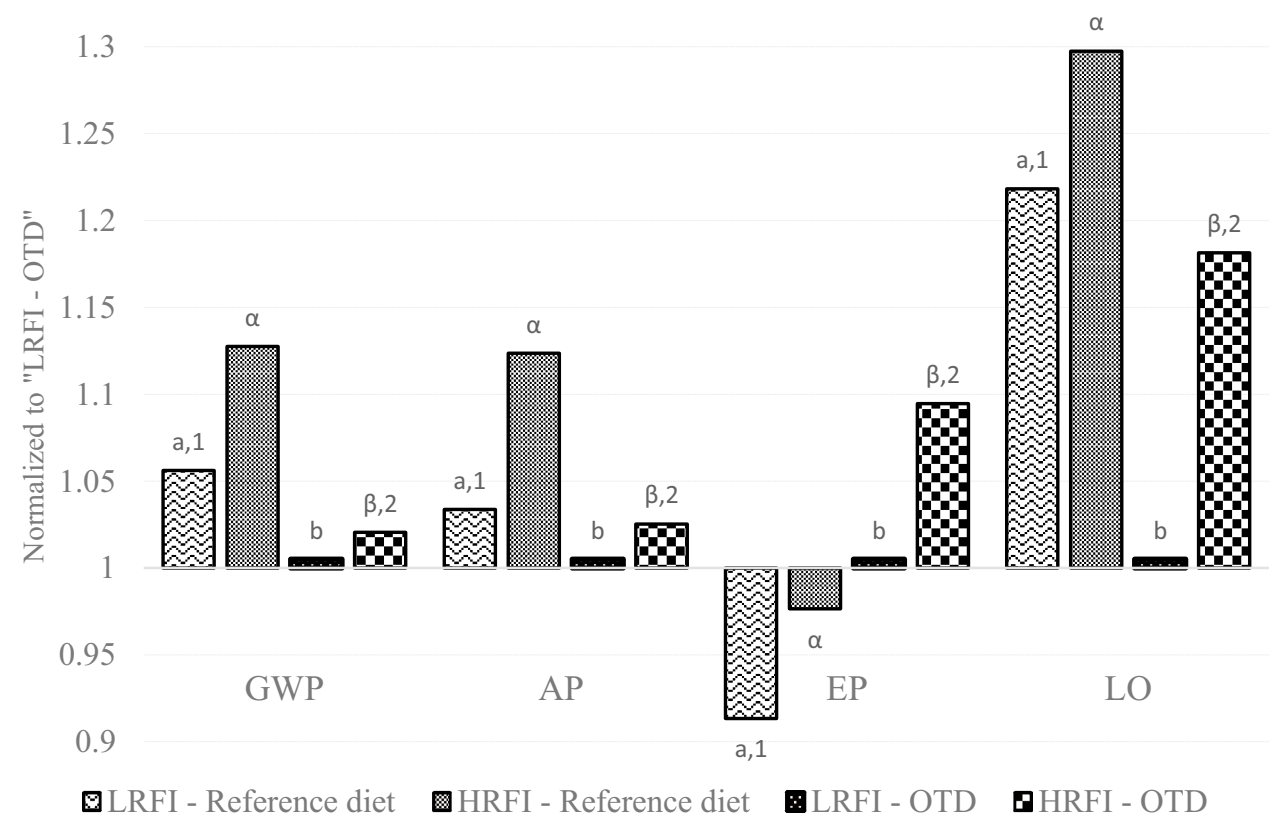

The original article has been corrected.

Open Access This article is licensed under a Creative Commons Attribution 4.0 International License, which permits use, sharing, adaptation, distribution and reproduction in any medium or format, as long as you give appropriate credit to the original author(s) and the source, provide a link to the Creative Commons licence, and indicate if changes were made. The images or other third party material in this article are included in the article's Creative Commons licence, unless indicated otherwise in a credit line to the material. If material is not included in the article's Creative Commons licence and your intended use is not permitted by statutory regulation or exceeds the permitted use, you will need to obtain permission directly from the copyright holder. To view a copy of this licence, visit http://creativecommons.org/licenses/by/4.0/.

Publisher's Note Springer Nature remains neutral with regard to jurisdictional claims in published maps and institutional affiliations. 